\title{
Bacterial vaginosis: drivers of recurrence and challenges and opportunities in partner treatment
}

\author{
Lenka A. Vodstrcil ${ }^{1,2,3^{*}}$ (D), Christina A. Muzny ${ }^{4}$, Erica L. Plummer ${ }^{1,2}$, Jack D. Sobel ${ }^{5}$ and Catriona S. Bradshaw ${ }^{1,2,3}$
}

\begin{abstract}
Bacterial vaginosis (BV) is the most common vaginal dysbiosis to affect women globally, yet an unacceptably high proportion of women experience BV recurrence within 6 months of recommended antibiotic therapy. The low rate of sustained cure highlights our limited understanding of the pathogenesis of BV recurrence, which has been attributed to possible persistence and re-emergence of BV-associated bacteria (BVAB) or a BV-associated biofilm following antimicrobials and/or reinfection occurring from sexual partners.

There is a robust body of evidence to support the exchange of bacteria between partners during sexual activity, and while the hypothesis that women treated for BV are subsequently reinfected with BVAB following sex with an untreated sexual partner is not new, failure of past partner treatment trials has eroded confidence in this concept. If reinfection is a key driver of recurrence, current antimicrobial regimens directed to women alone are unlikely to achieve a high level of sustained cure, and the approach of partner treatment to reduce reinfection is justified. In this manuscript, we present the molecular and epidemiological evidence that underlies the hypothesis that BV is sexually transmitted, and summarise why research that continues to consider sexual partnerships is necessary. We also outline the significant barriers and challenges that we have identified while undertaking partner treatment studies, and we discuss the factors that impact on our ability to determine their effectiveness.

Ultimately, the pathogenesis of BV recurrence is likely to be multifaceted and not attributable to a single mechanism in all women. If we are to achieve sustained cure for women, it is likely that combined and individualised approaches to eradicate $B \vee A B$, support an optimal vaginal microbiome, and prevent reinfection from partners will be required.
\end{abstract}

Keywords: Bacterial vaginosis, Male partners, Female partners, Treatment, Vaginal microbiota, Urethral microbiota, Penile microbiota, Metronidazole, Clindamycin, Sexually transmitted infection

\section{Background}

Bacterial vaginosis (BV) is the most prevalent vaginal condition, affecting $30 \%$ of women globally [1]. BV is associated with an increased risk of a broad range of gynaecological and obstetric sequelae including preterm

\footnotetext{
* Correspondence: lenka.vodstrcil@monash.edu

${ }^{1}$ Central Clinical School - Melbourne Sexual Health Centre, Monash

University, 580 Swanston St, Carlton, Victoria 3053, Australia

${ }^{2}$ Melbourne Sexual Health Centre, Alfred Health, Carlton, Victoria, Australia

Full list of author information is available at the end of the article
}

delivery, spontaneous abortion, early pregnancy loss in IVF, and HIV/STI acquisition and transmission [2-7]. Although up to half of BV-affected women do not experience symptoms $[8,9]$, for those that do, it is the symptoms themselves, including malodour and vaginal discharge, that cause significant distress to women and impact on their quality of life and relationships [10]. Current evidence indicates that BV is a polymicrobial syndrome characterised by a shift in the composition of the vaginal microbiota from 'optimal' to 'non-optimal'

(C) The Author(s). 2021 Open Access This article is licensed under a Creative Commons Attribution 4.0 International License, which permits use, sharing, adaptation, distribution and reproduction in any medium or format, as long as you give appropriate credit to the original author(s) and the source, provide a link to the Creative Commons licence, and indicate if changes were made. The images or other third party material in this article are included in the article's Creative Commons licence, unless indicated otherwise in a credit line to the material. If material is not included in the article's Creative Commons licence and your intended use is not permitted by statutory regulation or exceeds the permitted use, you will need to obtain permission directly from the copyright holder. To view a copy of this licence, visit http://creativecommons.org/licenses/by/4.0/ The Creative Commons Public Domain Dedication waiver (http://creativecommons.org/publicdomain/zero/1.0/) applies to the data made available in this article, unless otherwise stated in a credit line to the data. 
[11-14]. This non-optimal microbiological state involves a reduction in protective lactobacilli, and an increase in bacterial diversity and facultative and strict anaerobes, including Gardnerella spp., Atopobium vaginae, Prevotella spp., and others, referred to as BV-associated bacteria (BVAB) [11, 15]. While the exact pathogen/s responsible for $\mathrm{BV}$ are still debated, a recent conceptual model hypothesised that virulent strains of Gardnerella, as well as Prevotella bivia and A. vaginae, play a central role [16].

Recommended first-line antimicrobial treatments, metronidazole or clindamycin [17-20], provide broad anaerobic coverage and are administered orally or intravaginally. These regimens have similar efficacy and cure $\sim 70-85 \%$ of women with BV within 1 month [21, 22]; however, more than $50 \%$ experience recurrence of symptoms and/BV on microscopy within 6 months [23, 24]. The low rate of sustained cure not only highlights our incomplete understanding of the pathogenesis of BV recurrence, but also compounds women's distress and frustration, and leads to repeated presentation to health services or adoption of unproven home-remedies [10]. Factors including persistence of a BV-associated biofilm, failure to recolonise the vagina with lactobacilli, reinfection from an untreated partner, and host genetic and/or immune factors may all play a role in recurrence (Fig. 1) [25-29]. Frustratingly for both clinicians and patients, the contribution of reinfection and vaginal relapse cannot be separated, as the clinical presentation of both mechanisms of recurrence is identical. Point-of-care laboratory tests cannot resolve this issue yet, and molecular methods, including next generation sequencing, are unable to identify a unique or specific microbial signature to separate the two routes of recurrence $[11,15,30]$. While persistence or resistance of BVAB or BV biofilm following antibiotic therapy is likely to be the dominant mechanism among some women, there is a robust body of evidence to support the exchange of both optimal and detrimental bacteria between partners during sexual activity [31-35]. These data suggest that reinfection of women with pathogenic BVAB may be a key driver of recurrence following treatment [16, 26, 27, 36, 37]. If this is the case, current antimicrobial regimens directed solely to women are unlikely to achieve a high level of sustained cure.

Clinicians and researchers agree that there is an urgent need to develop more effective treatments to improve BV cure, and ultimately reduce adverse health outcomes [38]. In this review, we will discuss the disconnect between the epidemiological and microbiological evidence supporting the contribution of reinfection from an untreated sexual partner to the BV-syndrome, and the outcomes of prior trials that have evaluated partner

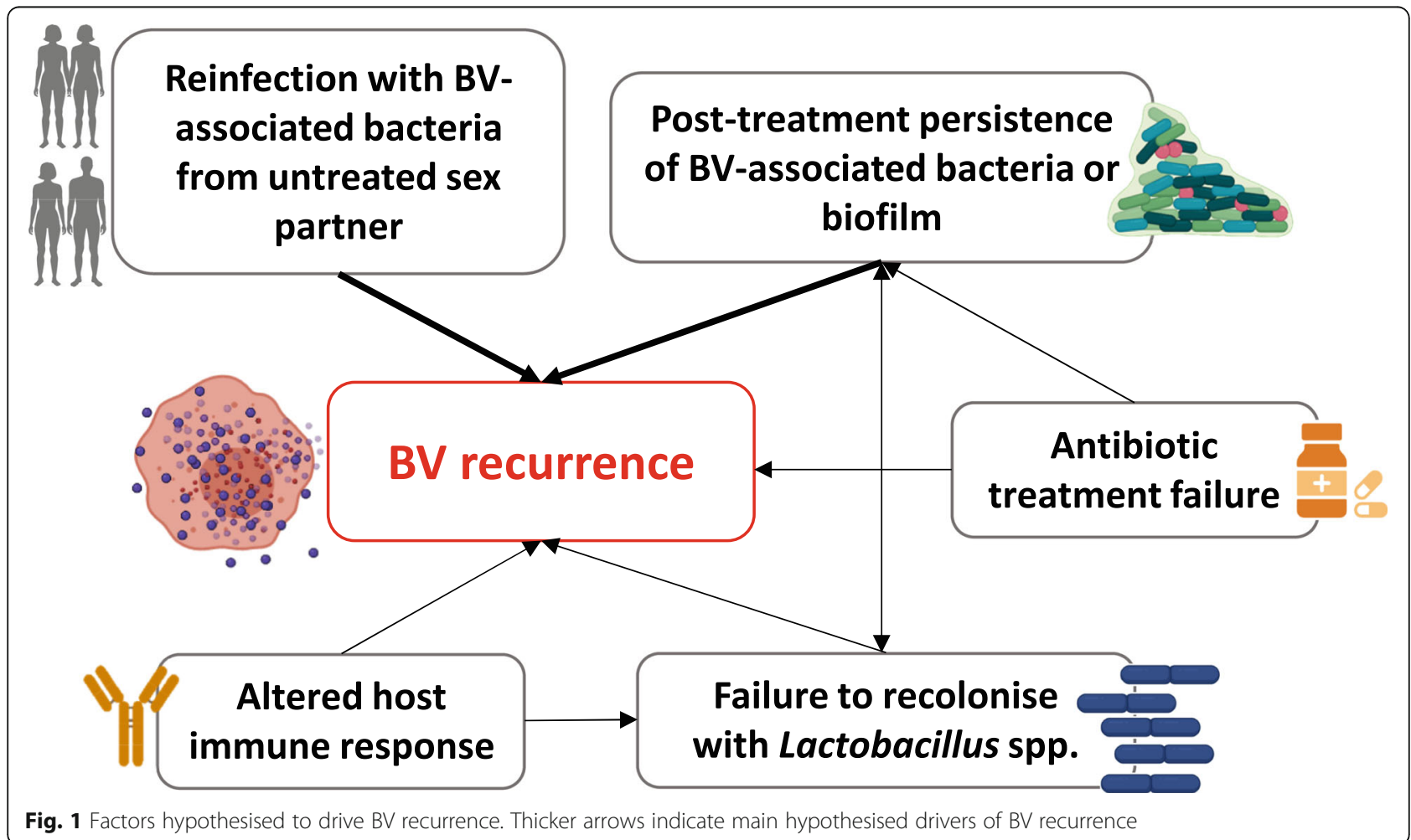


treatment to improve BV cure. We will outline the opportunities that sexual partner treatment may afford to women with BV and discuss the challenges faced when conducting partner treatment trials.

\section{Main text \\ Evidence to support sexual 'transmission' of the BV syndrome}

There is long standing evidence to support the contribution of sexual transmission to the pathogenesis of BV. In the 1950s, Gardner and Dukes first characterised BV and hypothesised that "...husbands must be treated simultaneously if recurrences by reinfection are to be prevented" [39]. When vaginal discharge was transferred from women with BV to those without, 11/15 women developed clinical signs and microbiological features of BV [39], indicating the BV syndrome was infectious. Initially, Gardnerella vaginalis was isolated from women with BV and hypothesised to be a new STI responsible for the syndrome; however, when 13 'healthy' women were inoculated with pure cultures of G. vaginalis (incubated for $24 \mathrm{~h}$ prior to inoculation and in the stationary phase of growth), only one developed BV [39]. In a subsequent study, which also used fresh cultures of G. vaginalis but incubated them for $12 \mathrm{~h}$ prior to inoculation and in the late logarithmic phase of growth, 5/9 women developed the BV syndrome [40]. This finding suggests that phase of growth and environmental signals may control expression of bacterial virulence factors which confer a greater pathogenic potential to G. vaginalis, a finding supported by more recent evidence [41]. In support of the initial hypothesis that G. vaginalis is the etiologic agent responsible for $\mathrm{BV}$, it was isolated from the urethra of 91/101 husbands of women with BV, but only 1/38 male medical students [42]. Successive studies also isolated G. vaginalis from the urethra of male partners of women with BV [43], and from a larger population of heterosexual men [44]. The high rates of BV recurrence post-treatment and evidence of male carriage of G. vaginalis led to six male-partner treatment trials of women with BV in the 1980s and 1990s (Table 1) [45-50]. Only one trial found a statistically significant reduction in BV recurrence [47], and the failure of the other trials was then interpreted as evidence against sexual transmission; thus, partner treatment is not currently recommended in guidelines [18, 54]. Lessons learned from these past trials and their limitations [53-55] are discussed later in this review.

What is clear now is that there is a substantial body of epidemiological and microbiological data to support the role of sexual transmission in the BV syndrome. As is the case for established STIs, prevalent BV is associated with earlier age of sexual debut [5658 ] and is uncommon in women reporting no sexual activity [58, 59]. In a 12-month cohort study, young women engaging in penile-vaginal sex were more likely to have a vaginal microbiota dominated by Gardnerella spp. than women reporting no sex [60], and in a cross-sectional study of 17 - and 18-year-old women, the presence and abundance of G. vaginalis, $A$. vaginae, and $P$. bivia was associated with history of penile-vaginal sex [61]. Furthermore, a metaanalysis showed a positive association between increased numbers of male sexual partners or a recent change of male partner and risk of BV (relative risk $[R R]=1.6,95 \% C I$ 1.5-1.8). Conversely, consistent condom use was associated with a decreased risk of BV $(\mathrm{RR}=0.8,95 \% \mathrm{CI} 0.8-0.9)$ [62]. The estimated protective effect of condom use for BV is similar in magnitude to the association reported between condom use and chlamydial and gonococcal infections (adjusted odds ratio $[\mathrm{aOR}]=0.82$, 95\% CI $0.66-1.01$ ) [63]. Furthermore, in a systematic review of risk factors for BV among women who have sex with women (WSW), BV was associated with increased number of lifetime female sexual partners, recent female partners, and sex with a partner with a concurrent BV diagnosis [64].

\section{The relationship between BV acquisition and sexual practices}

Incident BV has also been strongly associated with sexual practices and women reporting a new sexual partner are more likely to acquire BV $[36,65,66]$. Among women with male partners, penile-vaginal sex, inconsistent condom use, and semen exposure have been associated with $\mathrm{BV}$ acquisition/incidence $[67,68]$. However, BV transmission can occur in the absence of semen [69], and women engaging in sex with women also acquire BV. Studies of WSW have confirmed the relationship between BV acquisition and a number of sexual practices with women including sex with a new partner, and oral, digitalvaginal, and digital-anal sex $[36,64,66]$. In one 2year cohort study, WSW who reported a new sexual partner had a more diverse and unstable vaginal microbiota, characterised by Gardnerella spp. or other BVAB, and specific clades of Gardnerella were associated with different sexual practices [37, 70]. However, the timing between sampling and BV acquisition could not be accurately determined, as sampling only occurred at 3-month intervals. To further pinpoint the incubation period between exposure to BVAB and onset of BV, WSW providing daily vaginal specimens were followed for up to 90 days [71]. Among this cohort, an increase in the relative abundance of Gardnerella spp., P. bivia, and A. vaginae as well as the onset of the BV syndrome 
Table 1 Updated summary of prior male partner treatment trials aimed at reducing recurrent BV

\begin{tabular}{|c|c|c|c|c|c|c|c|}
\hline $\begin{array}{l}\text { First author } \\
\text { (year) }\end{array}$ & Location & $\begin{array}{l}\text { Sample } \\
\text { size }^{a}\end{array}$ & $\begin{array}{l}\text { Treatment } \\
\text { of women }\end{array}$ & $\begin{array}{l}\text { Treatment arm } \\
\text { for men }\end{array}$ & $\begin{array}{l}\text { Comparator } \\
\text { arm (men) }\end{array}$ & Primary outcome & Findings \\
\hline \multirow[t]{2}{*}{$\begin{array}{l}\text { Swedberg } \\
\text { (1985) [45] }\end{array}$} & \multirow{2}{*}{$\begin{array}{l}\text { Casper, } \\
\text { Wyoming, } \\
\text { USA }\end{array}$} & \multirow[t]{2}{*}{64} & $\begin{array}{l}\text { Oral MTZ } 2 \mathrm{~g} \\
\text { single dose OR }\end{array}$ & $\begin{array}{l}\text { Oral MTZ 2g single } \\
\text { dose OR }\end{array}$ & \multirow[t]{2}{*}{$\begin{array}{l}\text { Standard of } \\
\text { care }\end{array}$} & \multirow[t]{2}{*}{$\begin{array}{l}\text { Culture negative for G. vaginalis and } \\
\text { improved vaginal symptoms at } 21 \mathrm{~d}\end{array}$} & \multirow{2}{*}{$\begin{array}{l}68 \% \vee 64 \% \\
\mathrm{RR}=1.06 \\
95 \% \mathrm{Cl} 0.74 \\
1.52\end{array}$} \\
\hline & & & $\begin{array}{l}\text { Oral MTZ 500mg } \\
\text { bid 7d }\end{array}$ & $\begin{array}{l}\text { Oral MTZ 500mg bid } \\
7 \mathrm{~d}\end{array}$ & & & \\
\hline \multirow[t]{3}{*}{$\begin{array}{l}\text { Vejtorp } \\
\text { (1988) [46] }\end{array}$} & \multirow[t]{3}{*}{ Denmark } & \multirow[t]{3}{*}{106} & \multirow[t]{3}{*}{$\begin{array}{l}\text { Oral MTZ } 2 \mathrm{~g} \text { on } \\
\mathrm{d} 1 \text { and } 3\end{array}$} & \multirow[t]{3}{*}{$\begin{array}{l}\text { Oral MTZ } 2 \mathrm{~g} \text { on } \mathrm{d} 1 \\
\text { and } 3\end{array}$} & \multirow[t]{3}{*}{ Placebo } & Clinically diagnosed BV at 5w & $\begin{array}{l}25 \% \vee 29 \% \\
\mathrm{RR}=0.85 \\
95 \% \mathrm{Cl} 0.45 \\
1.61\end{array}$ \\
\hline & & & & & & G. vaginalis at $5 w$ & $\begin{array}{l}26 \% \vee 40 \% \\
\mathrm{RR}=0.64 \\
95 \% \mathrm{Cl} 0.37 \\
1.12\end{array}$ \\
\hline & & & & & & $\begin{array}{l}\text { Symptom improvement or cure at } \\
5 \mathrm{w}\end{array}$ & $\begin{array}{l}26 \% \vee 40 \% \\
\mathrm{RR}=0.64 ; \\
95 \% \mathrm{Cl} 0.83 \\
1.29\end{array}$ \\
\hline \multirow[t]{2}{*}{$\begin{array}{l}\text { Mengel } \\
(1989)[47]\end{array}$} & \multirow{2}{*}{$\begin{array}{l}\text { Seattle, } \\
\text { Washington, } \\
\text { USA }\end{array}$} & \multirow[t]{2}{*}{98} & $\begin{array}{l}\text { Oral MTZ } 2 \mathrm{~g} \\
\text { single dose OR }\end{array}$ & $\begin{array}{l}\text { Oral MTZ } 2 \mathrm{~g} \text { single } \\
\text { dose OR }\end{array}$ & \multirow[t]{2}{*}{ Placebo } & \multirow{2}{*}{$\begin{array}{l}\text { Symptoms and clinical cure of BV at } \\
2,5 \text {, and } 8 \text { w; BV on vaginal Gram } \\
\text { stain at } 2 \text { and } 5 \text { w }\end{array}$} & \multirow{2}{*}{$\begin{array}{l}\text { No point } \\
\text { estimates } \\
\text { reported }\end{array}$} \\
\hline & & & $\begin{array}{l}\text { Oral MTZ 500mg } \\
\text { bid 7d }\end{array}$ & $\begin{array}{l}\text { Oral MTZ 500mg bid } \\
7 d\end{array}$ & & & \\
\hline $\begin{array}{l}\text { Moi (1989) } \\
{[48]}\end{array}$ & $\begin{array}{l}\text { Denmark, } \\
\text { Finland, } \\
\text { Norway, } \\
\text { Sweden }\end{array}$ & 190 & $\begin{array}{l}\text { Oral MTZ } 2 \mathrm{~g} \text { on } \\
\mathrm{d} 1 \text { and } 3\end{array}$ & $\begin{array}{l}\text { Oral MTZ } 2 \mathrm{~g} \text { on } \mathrm{d} 1 \\
\text { and } 3\end{array}$ & Placebo & $\begin{array}{l}\text { Relapse of clinically diagnosed BV at } \\
12 \mathrm{w}\end{array}$ & $\begin{array}{l}21 \% \vee 16 \% \\
\mathrm{RR}=1.33 \\
95 \% \mathrm{Cl} 0.73- \\
2.44\end{array}$ \\
\hline $\begin{array}{l}\text { Vutyavanich } \\
\text { (1993) [49] }\end{array}$ & Thailand & 133 & $\begin{array}{l}\text { Oral TIN 2g single } \\
\text { dose }\end{array}$ & $\begin{array}{l}\text { Oral TIN } 2 \mathrm{~g} \text { single } \\
\text { dose }\end{array}$ & Placebo & Clinical cure of BV at $4 \mathrm{w}$ & $\begin{array}{l}72 \% \vee 63 \% \\
\mathrm{RR}=1.13 \\
95 \% \mathrm{Cl} 0.95 \\
1.35\end{array}$ \\
\hline $\begin{array}{l}\text { Colli (1997) } \\
{[50]}\end{array}$ & Italy & 139 & $\begin{array}{l}2 \% \text { clindamycin } \\
\text { intravaginal } \\
\text { cream } 7 \text { nights }\end{array}$ & $\begin{array}{l}\text { Oral clindamycin } \\
150 \mathrm{mg} \text { qid }\end{array}$ & Placebo & $\begin{array}{l}\text { Clinically diagnosed BV recurrence } \\
\text { at } 12 \mathrm{w}\end{array}$ & $\begin{array}{l}31.9 \% \mathrm{v} \\
30.0 \% \\
\mathrm{RR}=1.06 \\
95 \% \mathrm{Cl} 0.65- \\
1.75\end{array}$ \\
\hline $\begin{array}{l}\text { Schwebke } \\
\text { (2021) [51] }\end{array}$ & Multisite, USA & 214 & $\begin{array}{l}\text { Oral MTZ 500mg } \\
\text { bid } 7 d\end{array}$ & $\begin{array}{l}\text { Oral MTZ 500mg bid } \\
7 d\end{array}$ & Placebo & $\begin{array}{l}\text { BV cure defined as 0-2 Amsel } \\
\text { criteria and Nugent score 0-6 at } \\
16 \mathrm{w}\end{array}$ & $\begin{array}{l}81 \% \text { v } 80 \% \\
\text { Fisher's } \\
\text { exact test } \\
p>0.999\end{array}$ \\
\hline $\begin{array}{l}\text { Vodstrcil }^{c} \text { in } \\
\text { progress [52] }\end{array}$ & $\begin{array}{l}\text { Multisite, } \\
\text { Australia }\end{array}$ & $\begin{array}{l}\text { Aims to } \\
\text { recruit } \\
342\end{array}$ & $\begin{array}{l}\text { Oral MTZ 500mg } \\
\text { bid } 7 d^{d}\end{array}$ & $\begin{array}{l}\text { Oral MTZ 500mg bid } \\
\text { and topical } \\
\text { clindamycin bid } 7 \mathrm{~d}\end{array}$ & $\begin{array}{l}\text { Standard of } \\
\text { care }\end{array}$ & $\begin{array}{l}\text { BV recurrence defined as 3-4 Amsel } \\
\text { criteria and Nugent score } 4-10 \text { at } \\
12 \mathrm{w}\end{array}$ & in progress \\
\hline
\end{tabular}

Adapted from Mehta [53]; "standard of care" indicates female-only treatment; MTZ, metronidazole; TIN, tinidazole; $d$, days; $w$, weeks; $m$, months

asample size reflects those included in the analysis

${ }^{b}$ At 2 and $5 w$, women who had male sexual partners who received treatment showed less BV on vaginal Gram stain; these women also had fewer vaginal symptoms at 8 weeks

'Trial is currently recruiting (ACTRN12618000219280)

dWomen can receive topical clindamycin 7 nights if MTZ is contraindicated

occurred within approximately 4 days of sex, an incubation period analogous to that of other bacterial STIs (i.e. chlamydia, gonorrhoea) [71, 72].

Female couples provide additional proof of sexual exchange and sharing of the vaginal microbiota. Concordance of Nugent scores (the microbiological scoring method for BV) is high in women in monogamous relationships [73-75], and couples who both have BV are also concordant for specific BVAB [74]. Meanwhile, female couples without BV share lactobacillus strains associated with optimal vaginal microbiota, and $77 \%$ of monogamous couples have identical lactobacilli strainfingerprints [76]. Female monogamous couples who were $\mathrm{BV}$-negative at enrolment did not develop BV over 24 months [36], reflecting a shared stable optimal vaginal microbiome. Only after sex with a new partner outside of the relationship did women enrolling as a couple acquire BV. However, further research is needed into how specific bacterial strains may be transmitted and contribute to BV acquisition, and/or if there are any host factors that may render someone more susceptible to acquisition when exposed to a certain strain/s. 


\section{The relationship between recurrent BV and sexual practices}

While new sexual partnerships drive BV acquisition, the risk of BV recurrence following re-exposure to the same sexual partner after treatment increases 3-fold [26, 77]. This effect size was not reduced after adjustment for frequency of sex or condom use, which suggests that sexual exposure results in the exchange of organisms, rather than 'enhancing' or 're-activating' existing BVAB. Subsequent microbial sequencing found women who resumed sex with their ongoing partner following antibiotic treatment were more likely to have a vaginal microbiota colonised with BVAB than women without an ongoing partner [30]. Inconsistent condom use is another risk factor for BV recurrence [26, 77-79]. However, the effectiveness of condom use in preventing alterations to the composition of the vaginal microbiota needs further examination, with one study showing that women with inconsistent condom use had a similar relative abundance of BVAB to women reporting consistent use [30]. Further research is still needed to understand the key microbial drivers of recurrent BV, especially in the context of an ongoing partner that may be harbouring, and therefore reintroducing, specific BVAB.

\section{BVAB colonise the urethra and penile skin}

Early studies isolated $G$. vaginalis from the urethra of men [39, 42-44] and concordant G. vaginalis biotypes from the genitals of $11 / 12$ heterosexual couples [80]. Modern sequencing methods have provided extensive microbiological evidence of male carriage of BVAB at the penile skin and urethral sites [81]. Further, BVAB have also been shown to be more commonly detected in the sub-preputial region and distal urethra of male partners of women with BV than without $[33,82]$, and carriage of specific BVAB has been shown to be concordant between monogamous couples, with penile site-specific differences [31, 33-35]. In a pilot partner treatment trial, which treated male partners of women with BV with concurrent antibiotic treatment, several BVAB and Lactobacillus spp. were correlated between sexual partners, with a higher number of taxa correlated between the vaginal and cutaneous penile sites compared to the vaginal and urethral sites [83]. Interestingly, in the 12 weeks following treatment in couples where the female experienced BV recurrence, both Prevotella timonensis and Sneathia amnii were strongly positively correlated between the vagina and cutaneous penile site, whereas Lactobacillus iners was negatively correlated between the two sites. Conversely, among couples where women were cured, Lactobacillus spp. were positively correlated. These findings provide evidence that BVAB colonise men and indicate that taxa shared between a couple can differ depending on BV status. Fluorescence in situ hybridization studies have identified a Gardnerella biofilm in the urine of male partners of women with BV [84] and a polymicrobial BV biofilm in semen samples of male partners of women with BV [85]. Semen has been implicated in the BV syndrome [68], and the semen microbiota has been shown to alter the composition of the vaginal microbiota [32]. This effect has been hypothesised to be mediated by post-coital elevations in vaginal $\mathrm{pH}$; however, the increase in vaginal $\mathrm{pH}$ is transient; and it is more plausible that semen facilitates BV transmission by increasing the inoculum of BVAB. Whether there is an upper genital tract source for these BVAB in men or whether semen simply provides a vehicle to transfer urethral BVAB is not known.

The contribution of the cutaneous penile microbiota to BV acquisition in women was evident in a large circumcision trial in sub-Saharan Africa that had a primary aim of reducing HIV transmission. Circumcision was associated with a $40 \%$ reduced risk of a female partner acquiring $\mathrm{BV}$, and female partners of circumcised males carried fewer BVAB [86-88]. Furthermore, the total bacterial load and diversity of the coronal sulcus decreased 1 year after circumcision [82], with a significant reduction in the prevalence of BVAB and corresponding increase in non-BVAB. These studies suggest that among uncircumcised men, the coronal sulcus harbours higher loads of BVAB compared to circumcised men and points to the sub-preputial space as a key site for sexual exchange of BVAB. However, circumcision alone was unable to prevent BV acquisition in all women [86]. A recent prospective study following heterosexual couples demonstrated that meatal microbiota accurately predicted BV acquisition in female partners, and with more consistency than the cutaneous penile microbiota [89]. The taxa in the meatus that were considered most predictive of acquisition included Gardnerella, Parvimonas, Dialister, Sneathia sanguinegens, L. iners, and L. crispatus [89]. Interestingly, the composition at either penile site was able to accurately predict BV incidence at a higher rate than circumcision status [89]. Data from Plummer et al. highlight that the two penile sites harbour BVAB with differing tropism, and both may contribute to BV pathogenesis. Specifically, Gardnerella and Sneathia were abundant and prevalent at the urethral site, whereas Prevotella spp., Finegoldia, Peptoniphilus, and Anaerococcus were abundant and prevalent at the penile-skin site ([83] and personal communication).

Collectively, these data illustrate male carriage of BVAB and highlight how male partners and specific anatomical sites may contribute to BV acquisition and recurrence. While it is possible that some BVAB may comprise a 'normal' or 'healthy' penile skin and/or urethral microbiota, a comprehensive understanding of the male genital microbiota is needed to develop effective 
targeted interventions to determine if eradication or suppression of male carriage will prevent reinfection and acquisition of BV in women. Given the compelling epidemiological and microbiological evidence, it is logical to re-visit partner treatment to reduce BVAB carriage and improve long-term $\mathrm{BV}$ cure, taking into consideration the challenges faced in conducting these trials.

\section{What we can learn from past male-partner treatment trials}

More than 60 years ago, researchers and clinicians held the view that the syndrome of BV was sexually transmitted, or at least, associated with sex. The findings from the six male-partner treatment trials conducted in the 1980 s and 1990s have been extensively reviewed [5355], but we briefly summarise the findings (Table 1), with the aim of understanding the outcomes.

One of the challenges when assessing the effectiveness of partner treatment is that the trials utilised very different combinations of antibiotic treatments for differing durations (Table 1), and there was no published data to inform what treatments may be optimal for men. These trials had major trial-related limitations including small sample sizes, absence of power calculations, inconsistent and non-standard methods to diagnose BV in women, use of single-dose and non-standard treatments for women (which we now know are suboptimal), lack of data on treatment adherence, and high attrition [53, 55]. Another key difference between the trials was that the clinical endpoints were measured anywhere from 7 to 10 days to 12 weeks post-randomisation (Table 1). The timing of the endpoint may be critical in determining if an intervention is efficacious. Among couples counselled to abstain from sex, BV endpoints measured immediately post-treatment are more likely to reflect the efficacy of female-only treatment rather than the effect of treating the male on BV. In contrast, endpoints measured after a longer period of time post-treatment may be undermined by the introduction of untreated concurrent partners to the relationship. Overall, these limitations render the findings of these early trials inconclusive and cannot be used as evidence that BV is not sexually transmitted or that treating male partners will never be effective.

Since these two systematic reviews were published, we have the results from a recently conducted RCT [51]. Schwebke et al. treated women with recurrent BV with the current first-line regimen of 7-day oral metronidazole $500 \mathrm{mg}$ bid and their male sexual partners were randomised to concurrent treatment with the same regimen or an oral placebo (Table 1). This trial was the most thoroughly designed and addressed the limitations of prior trials, with sufficient sample size and clear power calculations, appropriate randomisation methods, blinding, and inclusion of data on antibiotic adherence. However, the trial was stopped early due to futility, as the primary-intention-to-treat analysis showed partner treatment did not improve cure by 16 weeks' postrandomisation. Even though these findings appear to be yet another notch against male-partner treatment, there are important considerations to note. The overall recurrence rate was $80 \%$ in women in both groups, which is higher than prior studies [23, 24], and may suggest the study population had underlying risk factors that placed them at high risk of recurrence, or persistent BV biofilm that is refractory to oral metronidazole. Further, post hoc analyses revealed that among couples where the man was $100 \%$ adherent to metronidazole treatment, the female partners were significantly less likely to recur (73\% vs. 97\% recurrence in women whose partners were $100 \%$ vs. $<100 \%$ adherent, respectively, $p<0.001)$. These findings suggest a modest effect of oral treatment in highly adherent males, but it is important to consider that oral therapy alone may also not sufficiently impact on cutaneous/sub-preputial carriage of BVAB.

\section{Moving forward: the challenges and opportunities of partner treatment}

Clearly, there are considerable challenges in undertaking partner treatment trials (Table 2). For these trials to work, it is imperative that they attempt to enrol 'closedcouple units' to ensure the efficacy of the intervention is not eroded by the introduction of untreated concurrent partners prior to endpoint. Of course, this is difficult, especially as the bulk of partner treatment studies recruit women from STI clinics, where concurrent partnerships are more common, and attendees are more likely to engage in higher risk sexual practices than the general population [90, 91]. Enrolling community-based cohorts and the use of a 'couples' verification tool' [92] may help to reduce the risk of enrolling a couple with external partners; however, external partnerships will not always be disclosed, with sexual behaviour data prone to bias and even more so when both individuals in a partnership are enrolled [93-96].

Table 2 Factors influencing the outcome of partner treatment trials

\begin{tabular}{l}
\hline Enrolment hesitancy or resistance \\
\hline Timely recruitment of partner \\
Study medication non-adherence \\
Barrier contraception use, especially during treatment \\
Concurrent sexual partnerships \\
Loss to follow up, particularly if treatment is effective \\
Selection bias of females with highly recurrent BV \\
(potential antimicrobial resistance, persistent tenacious biofilm)
\end{tabular}




\section{Partner treatment trials targeting male partners}

There are an additional set of challenges when recruiting couples to male-partner treatment trials. Women are often reluctant to disclose their symptoms to men [97] and may require educational material and support to increase their confidence in discussing their BV and the associated morbidities with their partner. Motivating male partners to participate is also made more difficult by the fact that most men do not experience symptoms themselves. This was highlighted by men participating in partner treatment trials, who reported BV to have little impact on themselves beyond their concerns for their partner's health, self-esteem, and confidence [97]. Interestingly, some men identified that the diagnosis of BV in their female partner led to improved communication with the partnership about sex and sexual health,and that accepting partner treatment showed they were committed to the relationship and could be a supportive partner [97]. Further research to identify the factors that may motivate male participants to participate in BV treatment trials is required.

Fundamentally, we also still do not know what the most appropriate and effective antibiotic agents are to use in male partners. Nearly all the RCTs to evaluate partner treatment used oral metronidazole (Table 1). Metronidazole, a nitroimidazole antibiotic with broad activity against anaerobic bacteria [98, 99], achieves 1month cure rates of $>80 \%$ among women [21, 22]. Less than $1 \%$ of anaerobic bacteria isolated from women pretreated with 5-day intravaginal metronidazole demonstrated resistance to metronidazole in vitro [100]. However, specific Gardnerella clades and other potentially pathogenic organisms including A. vaginae have been documented to show intrinsic resistance to metronidazole [101-107], and a BV-associated biofilm has also been shown to be resistant to metronidazole treatment $[25,108]$. Several other non-cultivatable organisms may also have resistance genes responsible for treatment failure [109]. Novel mechanisms by which metronidazole is ineffective have also been proposed; $L$. iners was recently demonstrated to sequester metronidazole in vitro, resulting in a lower efficacy of metronidazole against Gardnerella [110].

Many of the previous partner trials opted for stat $2 \mathrm{~g}$ doses of oral metronidazole to improve adherence, and we know adherence is essential to the success of any intervention; however, the short duration of activity of this single dose may have had limited impact on the male genital microbiota [51]. Newer single-dose nitroimidazoles approved for the treatment of BV, such as $2 \mathrm{~g}$ oral secnidazole [111], have similar efficacy to metronidazole but a longer half-life and thus may be more suited to partner treatment [112]. However, secnidazole and tinidazole have similar resistance patterns to metronidazole [113] and other drug classes or combinations of antimicrobials may be required to cover candidate BV pathogens. Clindamycin, which is commonly used in women with a contraindication to nitroimidazoles but also used first-line, is a lincosamide antibiotic with broad spectrum activity against Gram-positive cocci as well as anaerobic Gram-positive and Gram-negative bacteria. Clindamycin has been shown to have greater efficacy than the nitroimidazoles against $A$. vaginae, Gardnerella spp., and Mobiluncus spp. [113], and planktonic clinical isolates of Gardnerella exhibit a relatively higher susceptibility rate and lower resistance rate to clindamycin compared to metronidazole, suggesting clindamycin may be more optimal for reducing the abundance of Gardnerella [114]. While the effectiveness of metronidazole and clindamycin in clearing BVAB from women is still debated [115], data is needed to show if the effectiveness of these agents on BVAB in men. Newer biofilm-disrupting agents, for example dequalinium chloride [116] and TOL-463 [117], may be effective at disrupting BV biofilms in women and may also have a role in men, but this is yet to be determined. A registered RCT (NCT03412071 [118]) that aims to establish the effect of antimicrobial agents (oral tinidazole $2 \mathrm{~g}$ for $2 \mathrm{~d}$, penile topical metronidazole, topical clindamycin, or topical hydrogen peroxide) on the penile microbiota may provide some insight into the effect of different antimicrobials directed to men.

It is plausible that both penile skin and urethral carriage of $B V A B$ needs to be targeted if we are to achieve sufficient clearance of BVAB from the male genitalia and impact on reinfection in women. Two pilot partner treatment trials have targeted BVAB in men for 7 days at the distal urethra with $400 \mathrm{mg}$ metronidazole bid, and at the sub-preputial space and coronal sulcus with topical 2\% clindamycin cream applied bid [34, 83]. Treatment had an immediate effect on the composition of the penile-skin and urethral microbiota, with a decrease in the prevalence and abundance of BVAB; however, this change was not sustained at 1-3 months [34, 83]. Despite re-emergence of BVAB in men, the female partners of treated males experienced a significant and sustained decrease in the prevalence and abundance of BVAB to endpoint $[34,83]$. Although not powered to detect the effect of partner treatment, the pooled BV recurrence rate among the 50 couples undergoing treatment across both trials was only $8 \%$ at 1 month, and only $17 \%$ among the 29 couples followed to 3 months. Both are lower recurrence rates than would normally be expected in sexually active couples where a history of BV was common, as in other trials where recurrence among couples ranged from 40 to $80 \%[26,51,77]$. These data raise important questions: how effective does concurrent partner treatment need to be at reducing BVAB in men, and for 
what duration do the organisms need to be suppressed, to elicit a positive and sustained result in the female? Effective concurrent male-partner treatment may only need to disrupt the continued cycle of exposure to BVAB for a short period of time to provide women with an opportunity to recover post-treatment to a Lactobacillus-dominated state, capable of withstanding reexposure to $B V A B$ from their partner in the future.

The dual-therapy concurrent partner treatment approach is subject to an ongoing RCT (ACTRN12618000219280 [52];). A pragmatic open-label trial design is being used, with female-only treatment as the control group (i.e. current standard-of-care) compared to concurrent-couple treatment. In addition to the primary analysis, which will assess how this approach impacts cure rates, the specimens collected in this and the Schwebke RCT [51, 52] will inform our understanding of the short- and long-term impact of these antimicrobials on BVAB in both women and men, as well as the benefit of adherence to treatment.

\section{Partner treatment trials targeting female partners}

Despite BV being common among WSW, no partner treatment trials enrolling female couples have been conducted. As mentioned above, the majority (74-95\%) of female couples have been shown to be concordant for the presence or absence of BV [36, 74, 75]. If a female index case is enrolled in a partner treatment trial, it is highly likely that her female partner will be concordant for the presence of BV. Enrolling female couples would therefore provide an opportunity to determine the effectiveness of partner treatment in both members of the partnership. However, female-partner treatment brings a unique set of additional challenges. Enrolling BVconcordant couples in a blinded randomised partner treatment trial would mean that only half of the female partners would be treated for BV at enrolment, as the rest would be randomised to placebo. The concept of a placebo arm for women may not be accepted by participants or clinicians. Apprehension surrounding the ethics of non-treatment could be mitigated by considering firstly, that it has not been shown that treating BV prevents adverse outcomes, only symptoms [18], and if one of the partners has asymptomatic-BV at enrolment, treatment would not currently be recommended [18, 119]. FDA guidance around BV treatment trials also states that a placebo can be used as a comparator for the control arm [120], and recent BV treatment trials have done so $[111,121]$. Even if partner-treatment was accepted, in order to measure clinically meaningful cure, follow-up to 3-4 months is required, and it is quite likely that concerns around possible placebo therapy would lead to treatment seeking behaviour prior to endpoint. To address this, a rescue arm may need to be incorporated for partners who develop vaginal symptoms at any time during the trial so they can request evaluation and treatment of symptomatic BV and/or other vaginal infections, as is included in FDA guidance [120].

\section{Conclusions}

It is clear that current therapies that are solely directed to women have failed to achieve a high rate of sustained cure. By continuing to ignore the potential risk of sexual transmission and reinfection when evaluating the efficacy of treatments, the effectiveness of these strategies is likely to be consistently underestimated. When managing a patient with $\mathrm{BV}$, incorporating the regular partner who may be a source of reinfection provides an opportunity to make an impact on treatment outcomes. We need to continue to assess how antimicrobials change the genital microbiomes of both women with BV and their partner to ensure the most effective regimens are utilised. Furthermore, in order to overcome the short-comings of past partner treatment RCTs, we need innovative ways to engage women with $\mathrm{BV}$ and their partners to ensure recruitment of monogamous couples and promote adherence to treatment. Continued research into the pathogenicity of bacteria that are shared between couples may assist us in developing new treatment strategies, as well as providing evidence to support partner treatment as an adjunctive therapy to improve health outcomes for women.

Ultimately however, the pathogenesis of BV recurrence is complex, with reinfection likely to be important, but not the sole driver, of recurrence (Fig. 1). In some women, vaginal relapse (i.e. the re-emergence or persistence of BVAB) may be the dominant mechanism. There has been considerable focus recently on new therapeutic approaches aimed at biofilm eradication [116, 117], thereby removing the protected sanctuary containing bacterial pathogens and potentially eliminating a mechanism of BVAB persistence [122, 123], and some are included as alternative treatments in guidelines [19]. Similarly, evidence of antimicrobial resistance is reported; however, its contribution to recurrence is unclear and new antimicrobial drug classes have not been forthcoming [115]. The development of new molecular assays, which diagnose BV based on the specific pathogenic bacterial strains or the presence of anti-microbial resistance, may ultimately result in more precise and targeted therapies to improve cure. Given the failure of therapeutic solutions, the approach of partner treatment to prevent reinfection is justified. However, it is apparent to clinicians and researchers that a combination of strategies is likely to be required to achieve sustained cure and support the restoration of a vaginal microbiota associated with optimal sexual and reproductive health [27, 38 , 124]. This may involve the combined use for 
example of agents to disrupt BV biofilm [116, 117], more effective delivery of antibiotics, partner treatment, vaginal microbiome transplantation from 'healthy' donors with a Lactobacillus-dominated vaginal microbiota [125, 126], use of more promising probiotics such as Lactin-V [29], and/or agents such as lactic acid [127, 128]. For decades, we have made no impact on BV cure, and it is time to acknowledge that persisting with a one-size-fitsall approach is not only ineffective, but is unacceptable and costly to women, their relationships, and the healthcare system.

\section{Acknowledgements}

Not applicable

\section{Authors' contributions}

L.A.V., C.S.B. and C.A.M. conceived the review. L.A.V drafted the initial manuscript with initial feedback from C.S.B. and C.A.M., with subsequent review and feedback from E.L.P. and J.D.S. All authors read and approved the final manuscript.

\section{Funding}

E.L.P receives support from an Australian Government Research Training Program (RTP) Scholarship, C.S.B receives Australian NHMRC Leadership Investigator Grant funding (GNT1173361), and C.A.M receives R01 funding (R01Al146065-01A1) from the National Institute of Allergy and Infectious Diseases to study the pathogenesis of bacterial vaginosis.

\section{Availability of data and materials}

Not applicable

\section{Declarations}

Ethics approval and consent to participate

Not applicable

\section{Consent for publication}

Not applicable

\section{Competing interests}

L.A.V. and C.S.B. receive funding from the Australian National Health and Medical Research Council for research pertaining to bacterial vaginosis. Melbourne Sexual Health Centre has received fees for advice on clinical trials on bacterial vaginosis, which is unrelated to this work. C.A.M is a consultant for Lupin Pharmaceuticals, BioFire Diagnostics, Cepheid, and PhagoMed. C.A.M has also received research funding support from Lupin Pharmaceuticals as well as speaker honoraria from Abbott Molecular, Cepheid, Roche Diagnostics, and Becton Dickinson. J.D.S has served as a consultant for Scynexis Pharmaceuticals and Mycovia Pharmaceutical.

\section{Author details \\ ${ }^{1}$ Central Clinical School - Melbourne Sexual Health Centre, Monash University, 580 Swanston St, Carlton, Victoria 3053, Australia. ${ }^{2}$ Melbourne Sexual Health Centre, Alfred Health, Carlton, Victoria, Australia. ${ }^{3}$ Melbourne School of Population and Global Health, The University of Melbourne, Parkville, Victoria, Australia. ${ }^{4}$ Division of Infectious Diseases, University of Alabama at Birmingham, Birmingham, AL, USA. ${ }^{5}$ Division of Infectious Diseases, Wayne State University, Detroit, MI, USA.}

Received: 18 June 2021 Accepted: 28 July 2021

Published online: 02 September 2021

\section{References}

1. Peebles K, Velloza J, Balkus JE, McClelland RS, Barnabas RV. High global burden and costs of bacterial vaginosis: a systematic review and metaanalysis. Sex Transm Dis. 2019:46(5):304-11. https://doi.org/10.1097/OLQ. 0000000000000972
2. Koumans EH, Markowitz LE, Berman SM, St Louis ME. A public health approach to adverse outcomes of pregnancy associated with bacterial vaginosis. Int J Gynaecol Obstet. 1999;67:S29-33. https://doi.org/10.1016/ S0020-7292(99)00136-8.

3. Brotman RM, Klebanoff MA, Nansel TR, Yu KF, Andrews WW, Zhang J, et al. Bacterial vaginosis assessed by gram stain and diminished colonization resistance to incident gonococcal, chlamydial, and trichomonal genital infection. J Infect Dis. 2010;202(12):1907-15. https://doi.org/10.1086/657320.

4. Cohen CR, Lingappa JR, Baeten JM, Ngayo MO, Spiegel CA, Hong T, et al. Bacterial vaginosis associated with increased risk of female-to-male HIV-1 transmission: a prospective cohort analysis among African couples. PLoS Med. 2012;9(6):e1001251. https://doi.org/10.1371/journal.pmed.1001251.

5. Masson L, Passmore JA, Liebenberg L, Werner L, Baxter C, Arnold KB, et al. Genital inflammation and the risk of HIV acquisition in women. Clin Infect Dis. 2015;61(2):260-9. https://doi.org/10.1093/cid/civ298.

6. Alisoltani A, Manhanzva MT, Potgieter M, Balle C, Bell L, Ross E, Iranzadeh A, du Plessis M, Radzey N, McDonald Z, et al. Microbial function and genital inflammation in young South African women at high risk of HIV infection. Microbiome 2020;8:165. https://doi.org/10.1186/s40168-020-00932-8.

7. Skafte-Holm A, Humaidan P, Bernabeu A, Lledo B, Jensen JS, Haahr T. The association between vaginal dysbiosis and reproductive outcomes in subfertile women undergoing IVF-treatment: a systematic PRISMA review and meta-analysis. Pathogens. 2021;10(3):295.

8. Amsel R, Totten PA, Spiegel CA, Chen KC, Eschenbach D, Holmes KK. Nonspecific vaginitis. Diagnostic criteria and microbial and epidemiologic associations. Am J Med. 1983;74(1):14-22. https://doi.org/10.1016/0002-9343(83)91112-9.

9. Klebanoff MA, Schwebke JR, Zhang J, Nansel TR, Yu KF, Andrews WW. Vulvovaginal symptoms in women with bacterial vaginosis. Obstet Gynecol. 2004;104(2):267-72. https://doi.org/10.1097/01.AOG.0000134783.98382.b0.

10. Bilardi J, Walker S, McNair R, Mooney-Somers J, Temple-Smith M, Bellhouse $C$, et al. Women's management of recurrent bacterial vaginosis and experiences of clinical care: a qualitative study. PLoS One. 2016;11(3): e0151794. https://doi.org/10.1371/journal.pone.0151794.

11. Fredricks DN, Fiedler TL, Marrazzo JM. Molecular identification of bacteria associated with bacterial vaginosis. N Engl J Med. 2005;353(18):1899-911. https://doi.org/10.1056/NEJMoa043802.

12. Fettweis JM, Serrano MG, Sheth NU, Mayer CM, Glascock AL, Brooks JP, et al. Species-level classification of the vaginal microbiome. BMC Genomics. 2012; 13(Suppl 8):S17

13. Gajer P, Brotman RM, Bai G, Sakamoto J, Schutte UM, Zhong X, et al. Temporal dynamics of the human vaginal microbiota. Sci Transl Med. 2012; 4(132):132ra152.

14. McKinnon LR, Achilles SL, Bradshaw CS, Burgener A, Crucitti T, Fredricks DN, et al. The evolving facets of bacterial vaginosis: Implications for HIV transmission. AIDS Res Hum Retroviruses. 2019;35(3):219-28. https://doi. org/10.1089/aid.2018.0304.

15. Ravel J, Gajer P, Abdo Z, Schneider GM, Koenig SS, McCulle SL, et al. Vaginal microbiome of reproductive-age women. PNAS USA. 2011;108(Suppl 1): 4680-7. https://doi.org/10.1073/pnas.1002611107.

16. Muzny CA, Taylor CM, Swords WE, Tamhane A, Chattopadhyay D, Cerca N Schwebke JR. An updated conceptual model on the pathogenesis of bacterial vaginosis. J Infect Dis. 2019;220(9):1399-405. https://doi.org/10.1 093/infdis/jiz342.

17. UK National Guideline for the management of Bacterial Vaginosis. 2012:115. https://www.bashhguidelines.org/media/1041/bv-2012.pdf.

18. Workowski KA, Bolan GA. Sexually transmitted disease treatment guidelines, 2015. MMWR Recomm Rep. 2015;64(RR-3):1-137.

19. Sherrard J, Wilson J, Donders G, Mendling W, Jensen JS. 2018 European (IUSTI/WHO) International Union against sexually transmitted infections (IUSTI) World Health Organisation (WHO) guideline on the management of vaginal discharge. Int J STD AIDS. 2018;29(13):1258-72. https://doi.org/10.11 $77 / 0956462418785451$

20. Vaginitis in nonpregnant patients. ACOG Practice Bulletin, Number 215. Obstet Gynecol. 2020;135(1):e1-e17.

21. Koumans EH, Markowitz LE, Hogan V. Indications for therapy and treatment recommendations for bacterial vaginosis in nonpregnant and pregnant women: a synthesis of data. Clin Infect Dis. 2002;35(Suppl 2):S152-72. https://doi.org/10.1086/342103.

22. Oduyebo OO, Anorlu Rl, Ogunsola FT. The effects of antimicrobial therapy on bacterial vaginosis in non-pregnant women. Cochrane Database Syst Rev. 2009;3:CD006055 
23. Sobel JD, Schmitt C, Meriwether C. Long-term follow-up of patients with bacterial vaginosis treated with oral metronidazole and topical clindamycin. J Infect Dis. 1993;167(3):783-4. https://doi.org/10.1093/infdis/167.3.783.

24. Bradshaw CS, Morton AN, Hocking J, Garland SM, Morris MB, Moss LM, et al. High recurrence rates of bacterial vaginosis over the course of 12 months after oral metronidazole therapy and factors associated with recurrence. J Infect Dis. 2006;193(11):1478-89. https://doi.org/10.1086/503780.

25. Swidsinski A, Mendling W, Loening-Baucke V, Swidsinski S, Dorffel Y, Scholze J, et al. An adherent Gardnerella vaginalis biofilm persists on the vaginal epithelium after standard therapy with oral metronidazole. Am J Obstet Gynecol. 2008;198(1):97 e91-6.

26. Bradshaw CS, Vodstrcil LA, Hocking JS, Law M, Pirotta M, Garland SM, et al. Recurrence of bacterial vaginosis is significantly associated with posttreatment sexual activities and hormonal contraceptive use. Clin Infect Dis. 2013;56(6):777-86. https://doi.org/10.1093/cid/cis1030.

27. Bradshaw CS, Brotman RM. Making inroads into improving treatment of bacterial vaginosis - striving for long-term cure. BMC Infect Dis. 2015;15(1): 292. https://doi.org/10.1186/s12879-015-1027-4.

28. Muzny CA, Laniewski P, Schwebke JR, Herbst-Kralovetz MM. Host-vaginal microbiota interactions in the pathogenesis of bacterial vaginosis. Curr Opin Infect Dis. 2020;33(1):59-65. https://doi.org/10.1097/QC0.0000000000000620.

29. Cohen CR, Wierzbicki MR, French AL, Morris S, Newmann S, Reno H, et al. Randomized trial of Lactin- $V$ to prevent recurrence of bacterial vaginosis. N Engl J Med. 2020;382(20):1906-15. https://doi.org/10.1056/NEJMoa1915254.

30. Ratten LK, Plummer EL, Murray GL, Danielewski J, Fairley CK, Garland SM, et al. Sex is associated with the persistence of non-optimal vaginal microbiota following treatment for bacterial vaginosis: a prospective cohort study. BJOG. 2021;128(4):756-67. https://doi.org/10.1111/1471-0528.16430.

31. Eren AM, Zozaya M, Taylor CM, Dowd SE, Martin DH, Ferris MJ. Exploring the diversity of Gardnerella vaginalis in the genitourinary tract microbiota of monogamous couples through subtle nucleotide variation. PLoS One. 2011; 6(10):e26732. https://doi.org/10.1371/journal.pone.0026732.

32. Mandar R, Punab M, Borovkova N, Lapp E, Kiiker R, Korrovits P, et al. Complementary seminovaginal microbiome in couples. Res Microbiol. 2015; 166(5):440-7. https://doi.org/10.1016/j.resmic.2015.03.009.

33. Zozaya M, Ferris MJ, Siren JD, Lillis R, Myers L, Nsuami MJ, et al. Bacterial communities in penile skin, male urethra, and vaginas of heterosexual couples with and without bacterial vaginosis. Microbiome. 2016;4(1):16. https://doi.org/10.1186/s40168-016-0161-6.

34. Plummer EL, Vodstrcil LA, Danielewski JA, Murray GL, Fairley CK, Garland SM et al. Combined oral and topical antimicrobial therapy for male partners of women with bacterial vaginosis: acceptability, tolerability and impact on the genital microbiota of couples - a pilot study. PLoS One. 2018;13(1): e0190199. https://doi.org/10.1371/journal.pone.0190199.

35. Muzny CA, Van Der Pol W, Lefkowitz E, Ghosh A, Li M, Redden D, et al. 2408 Genital microbiomes of women with recurrent bacterial vaginosis and their regular male sexual partner. J Clin Translat Sci. 2018;2(S1):13. https://doi. org/10.1017/cts.2018.78.

36. Vodstrcil LA, Walker SM, Hocking JS, Law M, Forcey DS, Fehler G, et al. Incident bacterial vaginosis (BV) in women who have sex with women is associated with behaviors that suggest sexual transmission. Clin Infect Dis. 2015;60(7):1042-53. https://doi.org/10.1093/cid/ciu1130.

37. Plummer EL, Vodstrcil LA, Fairley CK, Tabrizi SN, Garland SM, Law MG, et al. Sexual practices have a significant impact on the vaginal microbiota of women who have sex with women. Sci Rep. 2019;9(1):19749. https://doi. org/10.1038/s41598-019-55929-7.

38. Unemo M, Bradshaw CS, Hocking JS, de Vries HJC, Francis SC, Mabey D, et al. Sexually transmitted infections: challenges ahead. Lancet Infect Dis. 2017;17(8):e235-79. https://doi.org/10.1016/S1473-3099(17)30310-9.

39. Gardner $\mathrm{HL}$, Dukes CD. Haemophilus vaginalis vaginitis: a newly defined specific infection previously classified non-specific vaginitis. Am J Obstet Gynecol. 1955;69(5):962-76. https://doi.org/10.1016/0002-9378(55)90095-8.

40. Criswell BS, Ladwig CL, Gardner HL, Dukes CD. Haemophilus vaginalis: vaginitis by inoculation from culture. Obstet Gynecol. 1969;33(2):195-9.

41. Patterson JL, Stull-Lane A, Girerd PH, Jefferson KK. Analysis of adherence, biofilm formation and cytotoxicity suggests a greater virulence potential of Gardnerella vaginalis relative to other bacterial-vaginosis-associated anaerobes. Microbiology. 2010;156(Pt 2):392-9. https://doi.org/10.1099/mic.0. 034280-0.

42. Gardner HL, Dukes CD. Hemophilus vaginalis vaginitis. Ann N Y Acad SCi. 1959;83:280-9. https://doi.org/10.1111/j.1749-6632.1960.tb40901.x.
43. Pheifer TA, Forsyth PS, Durfee MA, Pollock HM, Holmes KK. Nonspecific vaginitis: role of Haemophilus vaginalis and treatment with metronidazole. N Engl J Med. 1978;298(26):1429-34. https://doi.org/10.1056/NEJM1978062 92982601.

44. Dawson SG, Ison CA, Csonka G, Easmon CS. Male carriage of Gardnerella vaginalis. Br J Vener Dis. 1982;58(4):243-5. https://doi.org/10.1136/sti. 58.4.243.

45. Swedberg J, Steiner JF, Deiss F, Steiner S, Driggers DA. Comparison of single-dose vs one-week course of metronidazole for symptomatic bacterial vaginosis. Jama. 1985;254(8):1046-9. https://doi.org/10.1001/jama.1985.033 60080058029.

46. Vejtorp M, Bollerup AC, Vejtorp L, Fanoe E, Nathan E, Reiter A, et al. Bacterial vaginosis: a double-blind randomized trial of the effect of treatment of the sexual partner. Br J Obstet Gynaecol. 1988;95(9):920-6. https://doi.org/1 0.1111/j.1471-0528.1988.tb06581.x.

47. Mengel MB, Berg AO, Weaver CH, Herman DJ, Herman SJ, Hughes VL, et al. The effectiveness of single-dose metronidazole therapy for patients and their partners with bacterial vaginosis. J Fam Pract. 1989;28(2):163-71.

48. Moi H, Erkkola R, Jerve F, Nelleman G, Bymose B, Alaksen $K$, et al. Should male consorts of women with bacterial vaginosis be treated? Genitourin Med. 1989:65(4):263-8. https://doi.org/10.1136/sti.65.4.263.

49. Vutyavanich $T$, Pongsuthirak $P$, Vannareumol P, Ruangsri RA, Luangsook P. A randomized double-blind trial of tinidazole treatment of the sexual partners of females with bacterial vaginosis. Obstet Gynecol. 1993;82(4 Pt 1):550-4.

50. Colli $E$, Landoni M, Parazzini F. Treatment of male partners and recurrence of bacterial vaginosis: a randomised trial. Genitourin Med. 1997;73(4):267-70. https://doi.org/10.1136/sti.73.4.267.

51. Schwebke J, Lensing S, Lee J, Muzny CA, Pontius A, Woznicki N, Aguin T, Sobel JD. Treatment of male sexual partners of women with bacterial vaginosis (BV); a randomized, double-blind, placebo-controlled trial. Clin Infect Dis. 2021;73(3):e672-9.

52. Vodstrcil LA, Plummer EL, Doyle M, Fairley CK, McGuiness C, Bateson D, et al. Treating male partners of women with bacterial vaginosis (StepUp): a protocol for a randomised controlled trial to assess the clinical effectiveness of male partner treatment for reducing the risk of BV recurrence. BMC Infect Dis. 2020:20(1):834. https://doi.org/10.1186/s12879-020-05563-w.

53. Mehta SD. Systematic review of randomized trials of treatment of male sexual partners for improved bacterial vaginosis outcomes in women. Sex Transm Dis. 2012;39(10):822-30. https://doi.org/10.1097/OLQ.0b013e3182631d89.

54. Potter J. Should sexual partners of women with bacterial vaginosis receive treatment? Br J Gen Pract. 1999;49(448):913-8.

55. Amaya-Guio J, Viveros-Carreno DA, Sierra-Barrios EM, Martinez-Velasquez MY, Grillo-Ardila CF. Antibiotic treatment for the sexual partners of women with bacterial vaginosis. Cochrane Database Syst Rev. 2016;10:CD011701.

56. Larsson PG, Platz-Christensen JJ, Sundstrom E. Is bacterial vaginosis a sexually transmitted disease? Int J STD AIDS. 1991;2(5):362-4. https://doi. org/10.1177/095646249100200511.

57. Bukusi EA, Cohen CR, Meier AS, Waiyaki PG, Nguti R, Njeri JN, et al. Bacterial vaginosis: risk factors among Kenyan women and their male partners. Sex Transm Dis. 2006;33(6):361-7. https://doi.org/10.1097/01.olq.0000200551. 07573.df.

58. Fethers KA, Fairley CK, Morton A, Hocking JS, Hopkins C, Kennedy L, et al. Early sexual experiences and risk factors for bacterial vaginosis. J Infect Dis. 2009;200(11):1662-70. https://doi.org/10.1086/648092.

59. Fethers KA, Fairley CK, Morton A, Hocking JS, Fehler G, Kennedy L, et al. Low incidence of bacterial vaginosis in cohort of young Australian women. Sex Transm Dis. 2011;38(2):124-6. https://doi.org/10.1097/OLQ.0b013e3181 fobc37.

60. Vodstrcil LA, Twin J, Garland SM, Fairley CK, Hocking JS, Law MG, et al. The influence of sexual activity on the vaginal microbiota and Gardnerella vaginalis clade diversity in young women. PLoS One. 2017;12(2):e0171856. https://doi.org/10.1371/journal.pone.0171856.

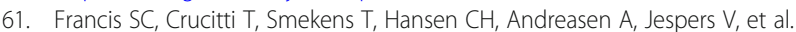
The vaginal microbiota among adolescent girls in Tanzania around the time of sexual debut. Front Cell Infect Microbiol. 2020;10:305. https://doi.org/1 0.3389/fcimb.2020.00305.

62. Fethers KA, Fairley CK, Hocking JS, Gurrin LC, Bradshaw CS. Sexual risk factors and bacterial vaginosis: a systematic review and meta-analysis. Clin Infect Dis. 2008;47(11):1426-35. https://doi.org/10.1086/592974.

63. Warner L, Newman DR, Austin HD, Kamb ML, Douglas JM Jr, Malotte CK, et al. Condom effectiveness for reducing transmission of gonorrhea and 
chlamydia: the importance of assessing partner infection status. Am J Epidemiol. 2004;159(3):242-51. https://doi.org/10.1093/aje/kwh044.

64. Forcey DS, Vodstrcil LA, Hocking JS, Fairley CK, Law M, McNair RP, et al. Factors associated with bacterial vaginosis among women who have sex with women: A systematic review. PLoS One. 2015;10(12):e0141905. https:// doi.org/10.1371/journal.pone.0141905.

65. Schwebke J, Desmond RA. Risk Factors for bacterial vaginosis in women at high risk for sexually transmitted diseases. Sex Transm Dis. 2005;32(11):6548. https://doi.org/10.1097/01.olq.0000175396.10304.62.

66. Marrazzo JM, Thomas KK, Fiedler TL, Ringwood K, Fredricks DN. Risks for acquisition of bacterial vaginosis among women who report sex with women: a cohort study. PLoS One. 2010;5(6):e11139. https://doi.org/10.13 71/journal.pone.0011139.

67. Hutchinson KB, Kip KE, Ness RB. Condom use and its association with bacterial vaginosis and bacterial vaginosis-associated vaginal microflora. Epidemiology. 2007;18(6):702-8. https://doi.org/10.1097/EDE.0b013e3181 567eaa.

68. Gallo MF, Warner L, King CC, Sobel JD, Klein RS, Cu-Uvin S, et al. Association between semen exposure and incident bacterial vaginosis. Infect Dis Obstet Gynecol. 2011;2011:842652.

69. Muzny CA, Schwebke JR. Suspected heterosexual transmission of bacterial vaginosis without seminal fluid exposure. Sex Transm Dis. 2014;41(1):58-60. https://doi.org/10.1097/OLQ.0000000000000057.

70. Plummer EL, Vodstrcil LA, Murray GL, Fairley CK, Danielewski JA, Garland SM, et al. Gardnerella vaginalis clade distribution is associated with behavioural practices and Nugent Score in women who have sex with women. J Infect Dis. 2020;221(3):454-63. https://doi.org/10.1093/infdis/jiz474.

71. Muzny CA, Blanchard E, Taylor CM, Aaron KJ, Talluri R, Griswold ME, et al. Identification of key bacteria involved in the induction of incident bacterial vaginosis: a prospective study. J Infect Dis. 2018;218(6):966-78. https://doi. org/10.1093/infdis/jiy243.

72. Muzny CA, Lensing SY. Aaron KJ. Incubation period and risk factors support sexual transmission of bacterial vaginosis in women who have sex with women. Sex Transm Infect: Schwebke JR; 2019.

73. Berger BJ, Kolton S, Zenilman JM, Cummings MC, Feldman J, McCormack WM. Bacterial vaginosis in lesbians: a sexually transmitted disease. Clin Infect Dis. 1995;21(6):1402-5. https://doi.org/10.1093/clinids/21.6.1402.

74. Marrazzo JM, Koutsky LA, Eschenbach DA, Agnew K, Stine K, Hillier SL. Characterization of vaginal flora and bacterial vaginosis in women who have sex with women. J Infect Dis. 2002;185(9):1307-13. https://doi.org/10.1 086/339884

75. Bradshaw CS, Walker SM, Vodstrcil LA, Bilardi JE, Law M, Hocking JS, et al. The influence of behaviors and relationships on the vaginal microbiota of women and their female partners: the WOW Health Study. J Infect Dis. 2014;209(10):1562-72. https://doi.org/10.1093/infdis/jit664.

76. Marrazzo JM, Antonio M, Agnew K, Hillier SL. Distribution of genital Lactobacillus strains shared by female sex partners. J Infect Dis. 2009;199(5): 680-3. https://doi.org/10.1086/596632.

77. Vodstrcil LA, Plummer ME, Fairley CK, Tachedjian G, Law MG, Hocking JS, et al. Combined oral contraceptive pill-exposure alone does not reduce the risk of bacterial vaginosis recurrence in a pilot randomised controlled trial. Sci Rep. 2019;9(1):3555. https://doi.org/10.1038/s41598-019-39879-8.

78. Sanchez S, Garcia PJ, Thomas KK, Catlin M, Holmes KK. Intravagina metronidazole gel versus metronidazole plus nystatin ovules for bacterial vaginosis: a randomized controlled trial. Am J Obstet Gynecol. 2004;191(6): 1898-906. https://doi.org/10.1016/j.ajog.2004.06.089.

79. Schwebke JR, Desmond RA. A randomized trial of the duration of therapy with metronidazole plus or minus azithromycin for treatment of symptomatic bacterial vaginosis. Clin Infect Dis. 2007;44(2):213-9. https://doi. org/10.1086/509577.

80. Piot P, Van Dyck E, Peeters M, Hale J, Totten PA, Holmes KK. Biotypes of Gardnerella vaginalis. J Clin Microbiol. 1984;20(4):677-9. https://doi.org/1 0.1128/jcm.20.4.677-679.1984

81. Nelson DE, Dong Q, Van Der Pol B, Toh E, Fan B, Katz BP, et al. Bacterial communities of the coronal sulcus and distal urethra of adolescent males. PLoS One. 2012;7(5):e36298. https://doi.org/10.1371/journal.pone.0036298.

82. Liu CM, Hungate BA, Tobian AA, Ravel J, Prodger JL, Serwadda D, et al. Penile microbiota and female partner bacterial vaginosis in Rakai, Uganda. MBio. 2015;6(3):e00589. https://doi.org/10.1128/mBio.00589-15.

83. Plummer EL, Vodstrcil LA, Fairley CK, Danielewski JA, Murray GL, Doyle M, et al. The impact of concurrent partner treatment for bacterial vaginosis on the genital microbiota of heterosexual couples: A pilot study. Sex Transm Infect. 2021;97(Suppl 1):A18.

84. Swidsinski A, Doerffel Y, Loening-Baucke V, Swidsinski S, Verstraelen $H$, Vaneechoutte M, et al. Gardnerella biofilm involves females and males and is transmitted sexually. Gynecol Obstet Invest. 2010;70(4):256-63. https://doi. org/10.1159/000314015.

85. Swidsinski A, Dorffel Y, Loening-Baucke V, Mendling W, Verstraelen $H$, Dieterle $\mathrm{S}$, et al. Desquamated epithelial cells covered with a polymicrobial biofilm typical for bacterial vaginosis are present in randomly selected cryopreserved donor semen. FEMS Immunol Med Microbiol. 2010;59(3):399_ 404. https://doi.org/10.1111/j.1574-695X.2010.00688.x.

86. Gray RH, Wawer MJ, Serwadda D, Kigozi G. The role of male circumcision in the prevention of human papillomavirus and HIV infection. J Infect Dis. 2009;199(1):1-3. https://doi.org/10.1086/595568.

87. Price LB, Liu CM, Johnson KE, Aziz M, Lau MK, Bowers J, et al. The effects of circumcision on the penis microbiome. PLoS One. 2010;5(1):e8422. https:// doi.org/10.1371/journal.pone.0008422.

88. Liu CM, Hungate BA, Tobian AA, Serwadda D, Ravel J, Lester R, et al. Male circumcision significantly reduces prevalence and load of genital anaerobic bacteria. MBio. 2013;4(2):e00076. https://doi.org/10.1128/mBio.00076-13.

89. Mehta SD, Zhao D, Green SJ, Agingu W, Otieno F, Bhaumik R, Bhaumik D, Bailey RC. The microbiome composition of a man's penis predicts incident bacterial vaginosis in his female sex partner with high accuracy. Frontiers in Cellular and Infection Microbiology 2020;10:433. https://doi.org/10.3389/ fcimb.2020.00433.

90. Sonnenberg P, Clifton S, Beddows S, Field N, Soldan K, Tanton C, et al. Prevalence, risk factors, and uptake of interventions for sexually transmitted infections in Britain: findings from the National Surveys of Sexual Attitudes and Lifestyles (Natsal). Lancet. 2013;382(9907):1795-806. https://doi.org/10.1 016/S0140-6736(13)61947-9.

91. Tanton C, Geary RS, Clifton S, Field N, Heap KL, Mapp F, et al. Sexual health clinic attendance and non-attendance in Britain: findings from the third National Survey of Sexual Attitudes and Lifestyles (Natsal-3). Sex Transm Infect. 2018;94(4):268-76. https://doi.org/10.1136/sextrans-2017-053193.

92. Muzny CA, Pontius A, Woznicki N, Hudak KE, Lensing SY, Sobel JD, et al. Use of a novel couples' verification tool in a male partner treatment study of women with recurrent bacterial vaginosis. Sex Transm Dis. 2020;47(12):e5861. https://doi.org/10.1097/OLQ.0000000000001225.

93. Weinhardt LS, Forsyth AD, Carey MP, Jaworski BC, Durant LE. Reliability and validity of self-report measures of HIV-related sexual behavior: progress since 1990 and recommendations for research and practice. Arch Sex Behav. 1998;27(2):155-80. https://doi.org/10.1023/A:101868253 0519.

94. Schroder KE, Carey MP, Vanable PA. Methodological challenges in research on sexual risk behavior: II. Accuracy of self-reports. Ann Behav Med. 2003; 26(2):104-23. https://doi.org/10.1207/S15324796ABM2602_03.

95. Tourangeau R, Yan T. Sensitive questions in surveys. Psychol Bull. 2007; 133(5):859-83. https://doi.org/10.1037/0033-2909.133.5.859.

96. DiClemente RJ, Sales JM, Danner F, Crosby RA. Association between sexually transmitted diseases and young adults' self-reported abstinence. Pediatrics. 2011:127(2):208-13. https://doi.org/10.1542/peds.2009-0892.

97. Wigan R, Vaughn C, Vodstrcil L, Doyle M, Kaiser M, McGuiness C, et al. "It's just an issue and you deal with it... you just deal with it, you move on and you do it together.": Men's experiences of bacterial vaginosis and the acceptability of male partner treatment. PLoS One. 2020;15(6):e0235286.

98. Lofmark S, Edlund C, Nord CE. Metronidazole is still the drug of choice for treatment of anaerobic infections. Clin Infect Dis. 2010;50(Suppl 1):S16-23. https://doi.org/10.1086/647939.

99. Sobel R, Sobel JD. Metronidazole for the treatment of vaginal infections. Expert Opin Pharmacother. 2015;16(7):1109-15. https://doi.org/10.1517/14 656566.2015.1035255.

100. Beigi RH, Austin MN, Meyn LA, Krohn MA, Hillier SL. Antimicrobial resistance associated with the treatment of bacterial vaginosis. Am J Obstet Gynecol. 2004;191(4):1124-9. https://doi.org/10.1016/j.ajog.2004.05.033.

101. Kharsany AB, Hoosen AA, Van den Ende J. Antimicrobial susceptibilities of Gardnerella vaginalis. Antimicrob Agents Chemother. 1993;37(12):2733-5. https://doi.org/10.1128/AAC.37.12.2733.

102. Simoes JA, Aroutcheva A, Heimler I, Shott S, Faro S. Bacteriocin susceptibility of Gardnerella vaginalis and its relationship to biotype, genotype, and metronidazole susceptibility. Am J Obstet Gynecol. 2001;185(5):1186-90. https://doi.org/10.1067/mob.2001.118144. 
103. Ferris MJ, Masztal A, Aldridge KE, Fortenberry JD, Fidel PL Jr, Martin DH. Association of Atopobium vaginae, a recently described metronidazole resistant anaerobe, with bacterial vaginosis. BMC Infect Dis. 2004;4(1):5. https://doi.org/10.1186/1471-2334-4-5.

104. De Backer E, Verhelst R, Verstraelen H, Claeys G, Verschraegen G, Temmerman $\mathrm{M}$, et al. Antibiotic susceptibility of Atopobium vaginae. BMC Infect Dis. 2006;6(1):51. https://doi.org/10.1186/1471-2334-6-51.

105. Nagaraja P. Antibiotic resistance of Gardnerella vaginalis in recurrent bacterial vaginosis. Indian J Med Microbiol. 2008;26(2):155-7. https://doi. org/10.4103/0255-0857.40531.

106. Alves P, Castro J, Sousa C, Cereija TB, Cerca N. Gardnerella vaginalis outcompetes 29 other bacterial species isolated from patients with bacterial vaginosis, using in an in vitro biofilm formation model. J Infect Dis. 2014; 210(4):593-6. https://doi.org/10.1093/infdis/jiu131.

107. Schuyler JA, Mordechai E, Adelson ME, Sobel JD, Gygax SE, Hilbert DW. Identification of intrinsically metronidazole-resistant clades of Gardnerella vaginalis. Diagn Microbiol Infect Dis. 2016;84(1):1-3. https://doi.org/10.1016/j. diagmicrobio.2015.10.006.

108. Swidsinski A, Dorffel Y, Loening-Baucke V, Schilling J, Mendling W. Response of Gardnerella vaginalis biofilm to 5 days of moxifloxacin treatment. FEMS Immunol Med Microbiol. 2010;61(1):41-6. https://doi.org/10.1111/j.1574695X.2010.00743.X

109. Javed A, Parvaiz F, Manzoor S. Bacterial vaginosis: an insight into the prevalence, alternative treatments regimen and it's associated resistance patterns. Microb Pathog. 2019;127:21-30. https://doi.org/10.1016/j.micpath.2 018.11.046.

110. Lee CY, Cheu RK, Lemke MM, Gustin AT, France MT, Hampel B, et al. Quantitative modeling predicts mechanistic links between pre-treatment microbiome composition and metronidazole efficacy in bacterial vaginosis Nat Commun. 2020;11(1):6147. https://doi.org/10.1038/s41467-020-19880-w.

111. Schwebke JR, Morgan FG, Jr., Koltun W, Nyirjesy P: A phase-3, double-blind, placebo-controlled study of the effectiveness and safety of single oral doses of secnidazole $2 \mathrm{~g}$ for the treatment of women with bacterial vaginosis. Am J Obstet Gynecol. 2017;217(6):e678.e1-678.e9.

112. De Backer E, Dubreuil L, Brauman M, Acar J, Vaneechoutte M. In vitro activity of secnidazole against Atopobium vaginae, an anaerobic pathogen involved in bacterial vaginosis. Clin Microbiol Infect. 2010;16(5):470-2. https://doi.org/10.1111/j.1469-0691.2009.02852.x.

113. Petrina MAB, Cosentino LA, Rabe LK, Hillier SL. Susceptibility of bacterial vaginosis (BV)-associated bacteria to secnidazole compared to metronidazole, tinidazole and clindamycin. Anaerobe. 2017;47:115-9. https://doi.org/10.1016/j.anaerobe.2017.05.005.

114. Li T, Zhang Z, Wang F, He Y, Zong X, Bai H, et al. Antimicrobial susceptibility testing of metronidazole and clindamycin against Gardnerella vaginalis in planktonic and biofilm formation. Can J Infect Dis Med Microbiol. 2020;2020: 1361825.

115. Sobel JD, Sobel R. Current and emerging pharmacotherapy for recurrent bacterial vaginosis. Expert Opin Pharmacother. 2021; Ahead of print:1-8. https://doi.org/10.1080/14656566.2021.1904890

116. Gaspar C, Rolo J, Cerca N, Palmeira-de-Oliveira R, Martinez-de-Oliveira J, Palmeira-de-Oliveira A. Dequalinium chloride effectively disrupts bacterial vaginosis (BV) Gardnerella spp. biofilms. Pathogens. 2021;10(3):261.

117. Marrazzo JM, Dombrowski JC, Wierzbicki MR, Perlowski C, Pontius A Dithmer D, et al. Safety and efficacy of a novel vaginal anti-infective, TOL463 , in the treatment of bacterial vaginosis and vulvovaginal candidiasis: a randomized, single-blind, phase 2, controlled trial. Clin Infect Dis. 2019;68(5): 803-9. https://doi.org/10.1093/cid/ciy554.

118. Galiwango RM, Bagaya B, Mpendo J, Joag V, Okech B, Nanvubya A, et al. Protocol for a randomized clinical trial exploring the effect of antimicrobial agents on the penile microbiota, immunology and HIV susceptibility of Ugandan men. Trials. 2019;20(1):443. https://doi.org/10.1186/s13063-019-3545-7.

119. Muzny CA, Schwebke JR. Asymptomatic bacterial vaginosis: to treat or not to treat? Curr Infect Dis Rep. 2020;22(12):32.

120. U.S. Department of Health and Human Services Food and Drug Administration, Center for Drug Evaluation and Research (CDER), Center for Biologics Evaluation and Research (CBER). Bacterial Vaginosis: Developing Drugs for Treatment, Guidance for Industry. 2019.

121. Hillier SL, Nyirjesy P, Waldbaum AS, Schwebke JR, Morgan FG, Adetoro NA et al. Secnidazole treatment of bacterial vaginosis: a randomized controlled trial. Obstet Gynecol. 2017;130(2):379-86. https://doi.org/10.1097/AOG. 0000000000002135 .
122. Machado D, Castro J, Palmeira-de-Oliveira A, Martinez-de-Oliveira J, Cerca N. Bacterial vaginosis biofilms: challenges to current therapies and emerging solutions. Front Microbiol. 2015;6:1528.

123. Muzny CA, Schwebke JR. Biofilms: an underappreciated mechanism of treatment failure and recurrence in vaginal infections. Clin Infect Dis. 2015; 61(4):601-6. https://doi.org/10.1093/cid/civ353.

124. Bradshaw CS, Sobel JD. Current treatment of bacterial vaginosis: limitations and need for innovation. J Infect Dis. 2016;214(Suppl 1):S14-20. https://doi. org/10.1093/infdis/jiw159.

125. Lev-Sagie A, Goldman-Wohl D, Cohen Y, Dori-Bachash M, Leshem A, Mor U, et al. Vaginal microbiome transplantation in women with intractable bacterial vaginosis. Nat Med. 2019;25(10):1500-4. https://doi.org/10.1038/s41 591-019-0600-6.

126. DeLong K, Bensouda S, Zulfiqar F, Zierden HC, Hoang TM, Abraham AG, et al. Conceptual design of a universal donor screening approach for vaginal microbiota transplant. Front Cell Infect Microbiol. 2019;9:306. https:// doi.org/10.3389/fcimb.2019.00306.

127. Tachedjian G, Aldunate M, Bradshaw CS, Cone RA. The role of lactic acid production by probiotic Lactobacillus species in vaginal health. Res Microbiol. 2017;168(9-10):782-92. https://doi.org/10.1016/j.resmic.2017.04.001.

128. Armstrong-Buisseret L, Brittain C, David M, Dean G, Griffiths F, Hepburn T, et al. Metronidazole versus lactic acid for treating bacterial vaginosis (VITA): protocol for a randomised controlled trial to assess the clinical and cost effectiveness of topical lactic acid gel for treating second and subsequent episodes of bacterial vaginosis. Trials. 2019;20(1):648. https://doi.org/10.1186/ s13063-019-3731-7.

\section{Publisher's Note}

Springer Nature remains neutral with regard to jurisdictional claims in published maps and institutional affiliations.

Ready to submit your research? Choose BMC and benefit from:

- fast, convenient online submission

- thorough peer review by experienced researchers in your field

- rapid publication on acceptance

- support for research data, including large and complex data types

- gold Open Access which fosters wider collaboration and increased citations

- maximum visibility for your research: over $100 \mathrm{M}$ website views per year

At $\mathrm{BMC}$, research is always in progress.

Learn more biomedcentral.com/submissions 